\title{
SYNTHESIS AND ANALYTICAL APPLICATION OF COPOLYMER RESIN DERIVED FROM MELAMINE
}

\section{S. S. RAHANGDALE ${ }^{1}$, W. B. GURNULE ${ }^{2}$}

${ }^{1}$ Department of Chemistry, Jagat Arts, Commerce and Indiraben Hariharbhai Patel Science College, Goregaon - 441 801, Maharashtra, India

${ }^{2}$ Department of Chemistry, Kamla Nehru Mahavidyalaya, Sakkardara, Nagpur 440009, Maharashtra, India

E-mail: rahangdaless@yahoo.com

\section{ABSTRACT:}

A novel chelating copolymer resin has been synthesized by condensation of p-aminobenzoic acid (p-AB) and melamine $(\mathrm{M})$ with formaldehyde $(\mathrm{F})$ in the presence of $2 \mathrm{M} \mathrm{HCl}$ as catalyst with different molar ratios of reacting monomers. Water pollution due to arsenic leaching is one of the biggest problems all over the world. Ion-exchange studies of this purified copolymer resin was carried out for $\mathrm{As}^{3+}$ ions. A copolymer proved to be a selective chelating ion-exchange copolymer for certain metals. Chelating ion-exchange properties of this copolymer were studied for $\mathrm{As}^{3+}$ ions. A batch equilibrium method was employed in the study of the selectivity of metal ion uptake involving the measurements of the distribution of a given metal ion between the polymer sample and a solution containing the metal ion. The study was carried out over a wide $\mathrm{pH}$ range and in media of various ionic strengths. The copolymer showed a higher selectivity for $\mathrm{As}^{3+}$ ions.

Keywords: Polycondensation, Copolymer, Ion-exchanger, Chelating resin

\section{INTRODUCTION:}

Chelation ion-exchange properties and thermal properties of copolymer resins derived from oxamide, melamine, p-cresol and formaldehyde reported ${ }^{18}$. Resin functionalized with dithiooxamide is found to be chelation ion exchangers ${ }^{6}$. Many copolymers with reactive groups are now being synthesized, tested and used not only for the macromolecular properties but also for the properties of functional groups. These functional groups provide an approach to a subsequent modification of the copolymers for specific end application ${ }^{1}$. In 
recent years, some comprehensive work has been published on functional monomers and their copolymers ${ }^{13}$. The interaction of heavy metal ${ }^{10}$ ions and chelating ion-exchange resin containing 8-hydroxyquinoline (8-HQ), The resin has good selectivity to exchangeable adsorption of heavy metal ions indicating $\mathrm{Cu}$ (II), $\mathrm{Hg}$ (II), $\mathrm{Pb}$ (II) and $\mathrm{Mg}$ (II) under $\mathrm{pH} 5.0$ and also suggested that the chelating ion-exchange resin containing 8-HQ could be used to enrich heavy metals in water and their analysis. Salih Bekir ${ }^{3}$ has prepared modified 1,4,8,11-tetraazocyclotridecane (cyclam) and with an AIBN initiator polymerized the modified cyclam. Cyclam containing polymer in bulk structure was removed from the suspension by filtration after washing and drying. The polymeric materials were used for transition metal ion adsorption and desorption of selected ions $\mathrm{Cu}$ (II), $\mathrm{Ni}$ (II), $\mathrm{Co}$ (II), $\mathrm{Cd}$ (II), and $\mathrm{Pb}$ (II) from aqueous media containing different amounts of these metal ions at different $\mathrm{pH}$ values. The adsorption rates were high and the adsorption equilibrium was reached in about $30 \mathrm{~min}$. The affinity order of the transition metal ions was $\mathrm{Cu}$ (II) $>\mathrm{Ni}$ (II) $>\mathrm{Co}$ (II) $>\mathrm{Cd}$ (II) $>\mathrm{Pb}$ for competitive adsorption. The chelating ionexchange properties of $8-\mathrm{HQMF}^{7}$ were studied for $\mathrm{Cu}^{+2}, \mathrm{Ni}^{+2}, \mathrm{Co}^{+2}, \mathrm{Zn}^{+2}, \mathrm{Cd}^{+2}$, $\mathrm{Fe}^{+3}$ and $\mathrm{Pb}^{+2}$ ions. A batch equilibrium method was used to study the selectivity of metal ion uptake by measuring the distribution of a metal ion between the resin sample and solution containing the metal ion. The study was carried out at different $\mathrm{pH}$ ranges and in medium of different ionic strengths. The copolymer showed higher selectivity for $\mathrm{Fe}$ (III), $\mathrm{Cu}$ (II) and Ni (II) ions than $\mathrm{Co}$ (II), $\mathrm{Zn}$ (II), Cd (II) and $\mathrm{Pb}$ (II) ions. A chelating terpolymer resin synthesized using an eco-friendly technique and reported its good binding capacity for $\mathrm{Ba}^{2+}$ and $\mathrm{Zn}^{2+}$ ions ${ }^{2}$. The chelating ability of the resin synthesized by a microwave irradiation technique involving salicylic acid and formaldehyde ${ }^{17}$.

The present study deals with synthesis and an application of chelating and functional polymers is their capability to recover metal ions from waste solutions. Hence, the chelating ion-exchange property of the p-ABMF copolymer resin was also reported for $\mathrm{As}^{3+}$ ions. 


\section{EXPERIMENT}

\section{MATERIALS:}

p-Aminobenzoic acid (Merck, India) and melamine (SRL, Mumbai) and were purified by rectified spirit, formaldehyde (37\%), metal chlorides and nitrates of selected metals (AR grade, Merck) were used as received.

\section{Synthesis of p-ABMF copolymer resin}

A mixture of p-amino benzoic acid (1.37 g, 0.1 mole), melamine (1.26 g, 0.1 mole), formaldehyde (10.5 ml, 0.3 mole) and $2 \mathrm{M}$ hydrochloric acid $(200 \mathrm{ml})$ was taken in RB flask fitted with water condenser and heated in an oil bath at $122 \pm 2^{\circ} \mathrm{C}$ for $5 \mathrm{hrs}$ with occasional shaking8-9. The temperature of electrically heated oil bath was controlled with the help of dimmer stat. The resinous solid product obtained was immediately removed from the flask as soon as the reaction period was over and then purified.

The resinous product so obtained was repeatedly washed with cold distilled water dried in air and powdered with the help of agate mortar and pestle. The powder was washed many times with hot water to remove unreacted monomers. The air dried powder then extracted with diethyl ether and then with petroleum ether to remove p-amino benzoic acid-formaldehyde copolymer which might be present along with $\mathrm{p}-\mathrm{ABMF}$ copolymer. It was further purified by dissolving in $8 \%$ sodium hydroxide solution, filtered and reprecipitated by gradual dropwise addition of ice cold 1: $1(\mathrm{v} / \mathrm{v})$ concentrated 
hydrochloric acid/distilled water with constant and rapid stirring to avoid lump formation. The process of reprecipitation was repeated thrice. The p-ABMF-I copolymer resin so obtained was filtered, washed several times with hot water, dried in air, powdered and kept in vacuum desicator over silica gel${ }^{9}$.

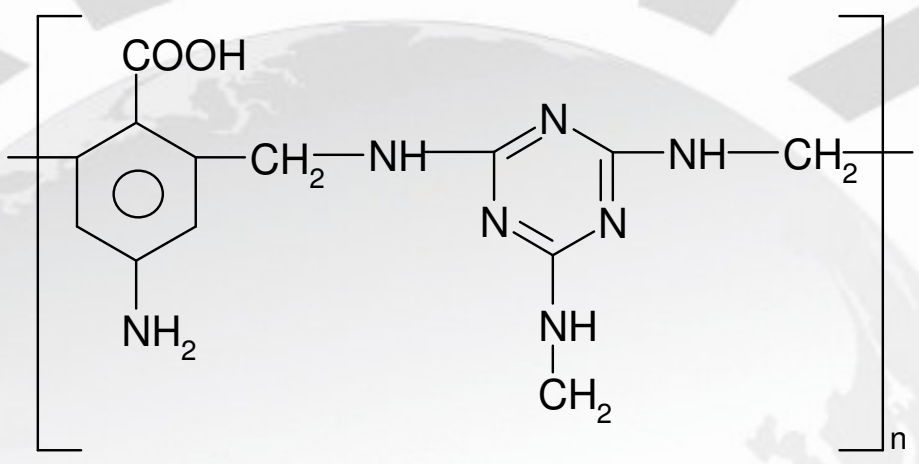

\section{Fig. 1 Structure of p-ABMF-I copolymer resin}

Similarly other copolymer resins viz., p-ABMF-II, p-ABMF-III and p-ABMF-IV were synthesized by varying the molar proportions of the starting materials i.e., (2:1:4), (3:1:5) and (4:2:7) respectively with little variation of experimental conditions. The samples, yields and reaction details are cited in Table 1.

\section{Melting Temperature of Copolymer Resins:}

Melting temperature of all copolymer resins were determined by the usual technique employed for the organic compounds. Accurate melting temperature for each of the copolymer resins has been noted by using a melting point apparatus, Tempo, A- 122 model. The experimentally obtained melting temperatures for different copolymer resins are tabulated in Table 1. 


\begin{tabular}{|c|c|c|c|c|c|c|c|c|}
\hline \multicolumn{3}{|c|}{ Reactants } & \multirow{2}{*}{$\begin{array}{c}\text { Catalys } \\
\text { t } \\
\text { 2M HCl } \\
\text { (aq) } \\
\text { (ml) }\end{array}$} & \multirow{2}{*}{$\begin{array}{l}\text { Reflux } \\
\text { temp. }\end{array}$} & \multirow{2}{*}{$\begin{array}{c}\text { Resin } \\
\text { Abbreviat } \\
\text { ion }\end{array}$} & \multirow{2}{*}{$\begin{array}{l}\text { Molar } \\
\text { ratio of } \\
\text { reacta } \\
\text { nts }\end{array}$} & \multirow{2}{*}{$\begin{array}{c}\text { Yield } \\
\text { (\%) }\end{array}$} & \multirow{2}{*}{$\begin{array}{l}\text { Meltin } \\
\text { g } \\
\text { temp. } \\
\text { of } \\
\text { resin } \\
\text { (K) }\end{array}$} \\
\hline $\begin{array}{c}\text { p-amino } \\
\text { benzoic } \\
\text { acid 'p- } \\
\text { AB' } \\
\text { (mole) }\end{array}$ & $\begin{array}{c}\text { Melami } \\
\text { ne } \\
\text { 'M' } \\
\text { (mole) }\end{array}$ & $\begin{array}{c}\text { Formaldeh } \\
\text { yde } \\
\text { 'F' } \\
\text { (mole) }\end{array}$ & & & & & & \\
\hline 0.1 & 0.1 & 0.3 & 200 & 395 & p-ABMF-I & $1: 1: 3$ & $80 \%$ & 448 \\
\hline 0.2 & 0.1 & 0.4 & 200 & 395 & p-ABMF-II & $2: 1: 4$ & $78 \%$ & 474 \\
\hline 0.3 & 0.1 & 0.5 & 200 & 395 & $\begin{array}{c}\text { p-ABMF- } \\
\text { III }\end{array}$ & $3: 1: 5$ & $81 \%$ & 481 \\
\hline 0.4 & 0.2 & 0.7 & 200 & 395 & $\begin{array}{c}\text { p-ABMF- } \\
\text { IV }\end{array}$ & $4: 2: 7$ & $76 \%$ & 503 \\
\hline
\end{tabular}

\section{Ion-exchange properties}

The ion-exchange properties of the $\mathrm{p}-\mathrm{ABMF}$ copolymer resins were determined by the batch equilibrium method ${ }^{19}$. The ion exchange properties of all the four resins have been studied. However, only the data for the p-ABMF-1 copolymer resin has been presented in this paper.

\section{Determination of metal uptake in the presence of various electrolytes and}

\section{different concentration}

The copolymer sample $(25 \mathrm{mg})$ was suspended in an electrolyte solution $(25 \mathrm{~mL})$ of known concentration. The $\mathrm{pH}$ of the suspension was adjusted to the required value by using either $0.1 \mathrm{M} \mathrm{HNO}_{3}$ or $0.1 \mathrm{M} \mathrm{NaOH}$. The suspension was stirred for $24 \mathrm{hrs}$ at $30^{\circ} \mathrm{C}$. To this suspension $2 \mathrm{ml}$ of $0.1 \mathrm{M}$ solution of the metal ion was added and the $\mathrm{pH}$ was adjusted to the required value. The mixture was again stirred at $30^{\circ} \mathrm{C}$ for $24 \mathrm{~h}$. The polymer was then filtered off 
and washed with distilled water. The filtrate and the washing were collected and then the amount of metal ion was estimated by titrating against standard EDTA (ethylene diamine tetra-acetic acid) at the same $\mathrm{pH}$ (experimental reading). The same titration has been carried out without polymer (blank reading). The amount of metal ion uptake of the polymer was calculated from the difference between a blank experiment without polymer and the reading in the actual experiments. The experiment was repeated in the presence of several electrolytes ${ }^{20}$. Metal ion, its $\mathrm{pH}$ range, buffer used, indicator used and colour change are given in Table 3 . The metal ion uptake can be determined as, Metal ion adsorbed (uptake) by resin $=(X-Y) ~ Z \mathrm{mmol} / \mathrm{g}$.

Where,

$\mathrm{Z}(\mathrm{mL})$ is the difference between actual experimental reading and blank reading.

$\mathrm{X}(\mathrm{mg})$ is metal ion in the $2 \mathrm{ml} 0.1 \mathrm{M}$ metal nitrate solution before uptake.

$\mathrm{Y}(\mathrm{mg})$ is metal ion in the $2 \mathrm{ml} 0.1 \mathrm{M}$ metal nitrate solution after uptake.

By using this equation the uptake of various metal ion by resin can be calculated and expressed in terms of milliequivalents per gram of the copolymer.

\section{Estimation of rate of metal ion uptake as function of time}

In order to estimate the time require to reach the state of equilibrium under the given experimental conditions, a series of experiments of the type described above were carried out, in which the metal ion taken up by the 
chelating resins was determined from time to time at $30^{\circ} \mathrm{C}$ (in the presence of $25 \mathrm{~mL}$ of $1 \mathrm{M} \mathrm{NaNO}$ solution). It was assumed that, under the given conditions, the state of equilibrium was established within $24 \mathrm{~h}^{15}$. The rate of metal uptake is expressed as percentage of the amount of metal ions taken up after a certain time related to that at the state of equilibrium and it can be defined by the following relationship.

The percent amount of metal ions taken up at different time is defined

as.

Percentage of amount of Amount of metal ion adsorbed metal ion taken up at $=\overline{\text { Amount of metal ion adsorbed at }} \times 100$ different time equilibrium

Percentage of metal ion adsorbed after $1 \mathrm{hr}=(100 \mathrm{X}) / \mathrm{Y}$

Where, $\mathrm{X}$ is $\mathrm{mg}$ of metal ion adsorbed after $1 \mathrm{~h}$ and $\mathrm{Y}$ is $\mathrm{mg}$ of metal ion is adsorbed after $25 \mathrm{~h}$, then by Using this expression, the amount of metal adsorbed by polymer after specific time intervals was calculated and expressed in terms of percentage metal ion adsorbed. This experiment was performed using $0.1 \mathrm{M}$ metal nitrate solution of $\mathrm{As}^{3+}$.

\section{Evaluation of the distribution of metal ions at different $\mathrm{pH}$}

The distribution of each one of the metal ions i.e., $\mathrm{As}^{3+}$ between the polymer phase and the aqueous phase was determined at $30{ }^{\circ} \mathrm{C}$ and in the presence of $1 \mathrm{M} \mathrm{NaNO}$ solution. The experiments were carried out as described 
above at different $\mathrm{pH}$ values. The distribution ratio, $\mathrm{D}$, is defined by the following relationship ${ }^{14}$.

$\mathrm{D}=\frac{\text { Amount of metal ion on re sin }}{\text { Amount of metal ion in solution }} \times \frac{\text { Volume of solution }(\mathrm{ml})}{\text { Weight of resin }(\mathrm{g})}$

Metal ion adsorbed (uptake) by the resin $=\left(\frac{Z X}{Y}\right) \frac{2}{0.025}$

Where $Z$ is the difference between actual experiment reading and blank reading, $\mathrm{C}(\mathrm{g})$ is the amount of metal ion in $2 \mathrm{~mL} 0.1 \mathrm{M}$ metal nitrate solution, and $\mathrm{Y}(\mathrm{g})$ of metal ion in $2 \mathrm{~mL}$ of metal nitrate solution after uptake.

\section{RESULTS AND DISCUSSION:}

\section{Ion-Exchange Properties}

The results of the batch equilibrium study carried out with the copolymer resin sample p-ABMF-I are presented in Fig. 2 to 7 . From this study with five metal ions under limited variation of experimental conditions, certain generalization may be made about the behaviour of the copolymer sample.

\section{Effect of Electrolytes on Metal Uptake}

The effect of electrolyte and its ionic strength on metal uptake by polymer was estimated $\mathrm{As}^{3+}$ using four different electrolytes with five different concentrations of each. We examined the influence of $\mathrm{ClO}_{4}^{-}, \mathrm{NO}_{3}^{-}, \mathrm{Cl}^{-}$and $\mathrm{SO}_{4}^{2-}$ at various concentrations on the equilibrium of metal - resin interaction. Fig. 2 to 5 shows the amount of metal ions taken up by a given amount of copolymer depends on the nature and concentration of the electrolyte present in the solution. In the presence of perchlorate, chloride and nitrate ions, the uptake of $\mathrm{As}^{3+}$ ions increases with increasing concentration of the electrolyte, whereas in the presence of sulfate ions the amount of the above mentioned ions taken up by the copolymer decreases with increasing concentration of the electrolyte. 
This may be explained on the stability constant of the complexes with those metal ions.

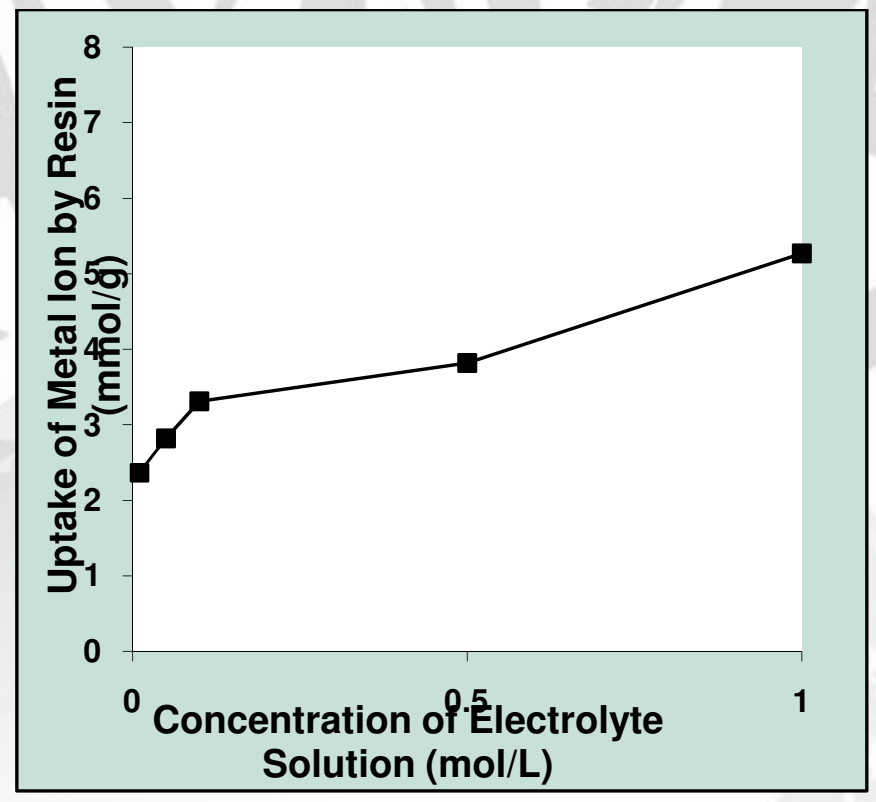

Fig. 2: Uptake of metal ion by p-ABMF -I copolymer resin at five different concentrations of $\mathrm{NaNO}_{3}$ electrolyte solution

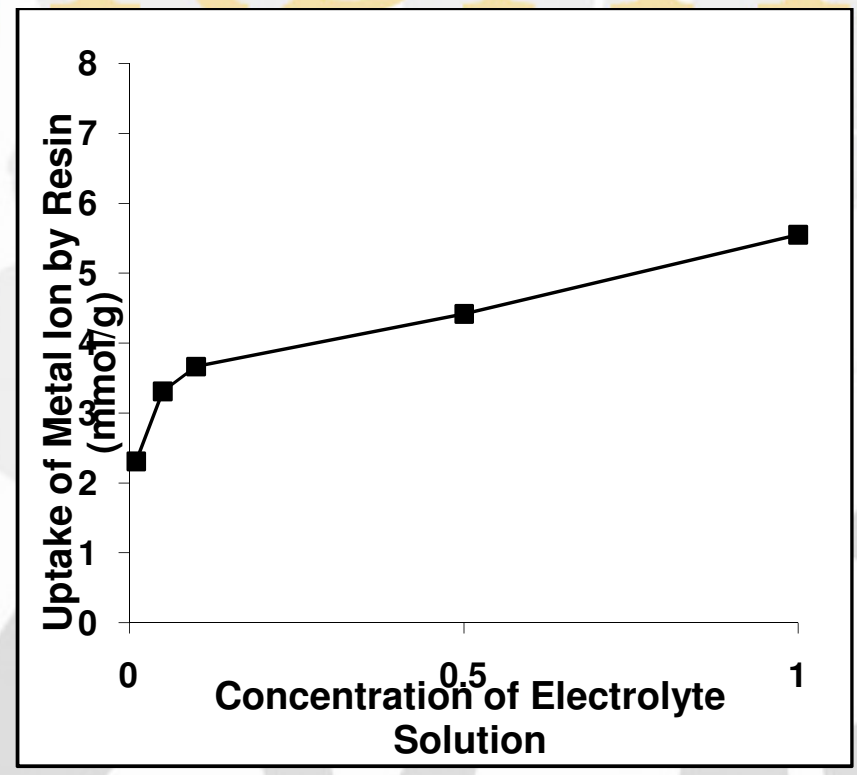

Fig. 3: Uptake of metal ion by p-ABMF -I copolymer resin at five different concentrations of $\mathrm{NaCl}$ electrolyte solution 


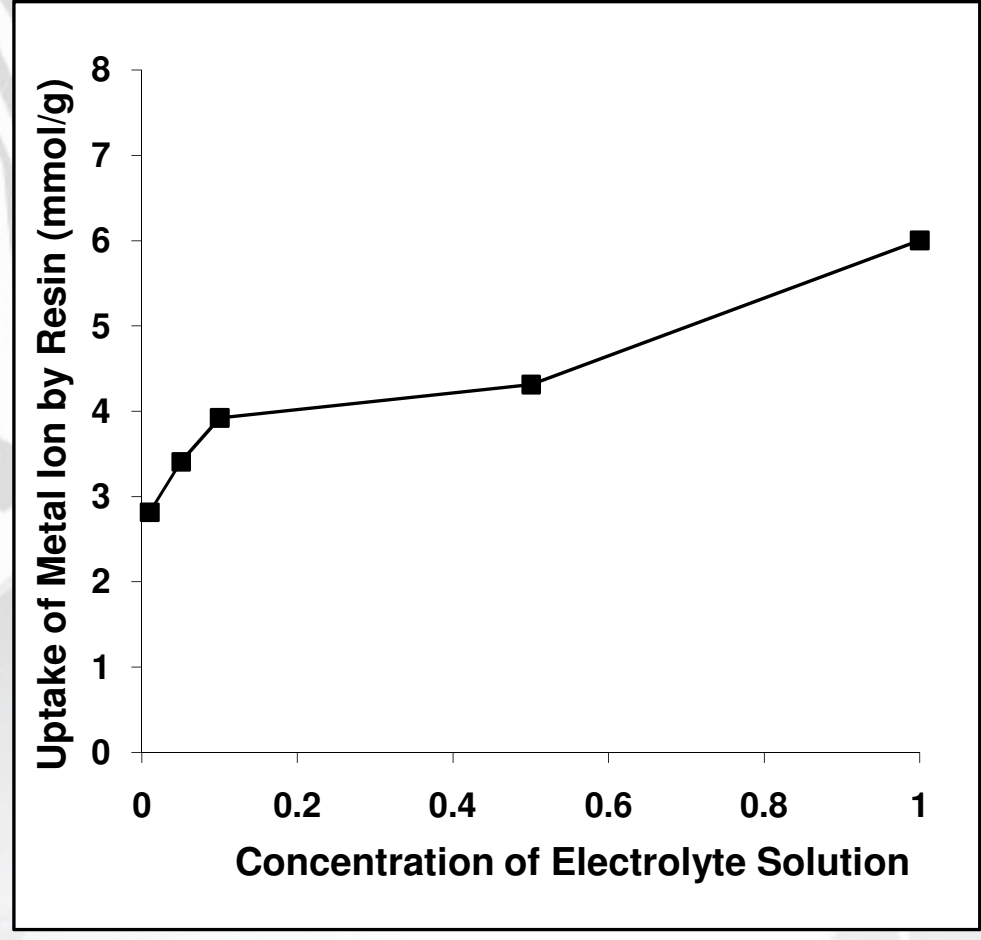

Fig. 4: Uptake of metal ion by p-ABMF -I copolymer resin at five different concentrations of $\mathrm{NaClO}_{4}$ electrolyte solution

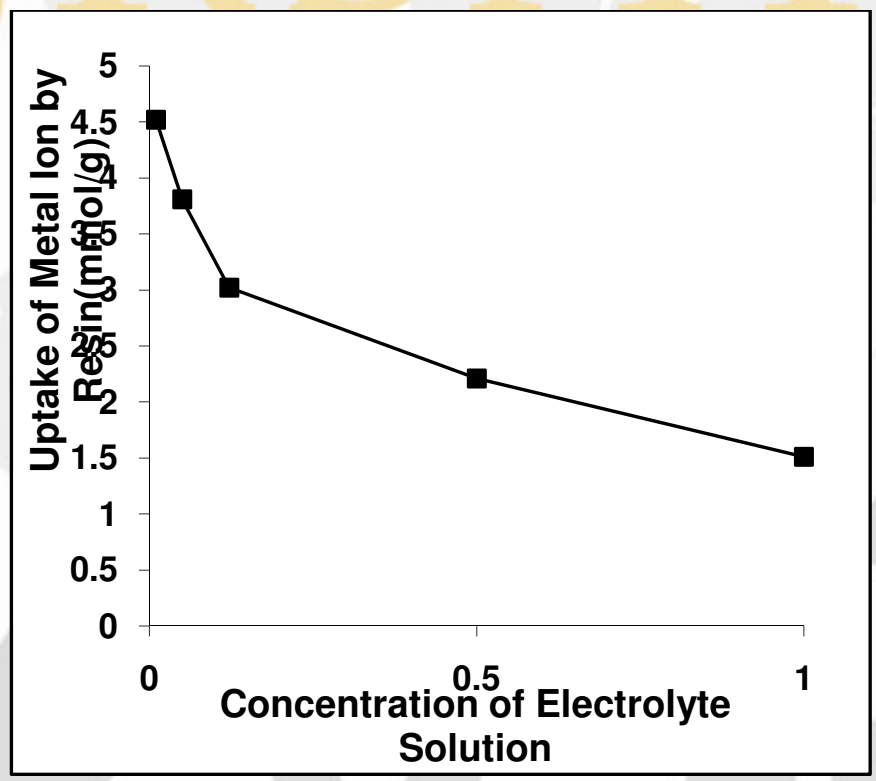

Fig. 5: Uptake of metal ion by p-ABMF -I copolymer resin at five different concentrations of $\mathrm{Na}_{2} \mathrm{SO}_{4}$ electrolyte solution 


\section{Rate of Metal Ion Uptake}

The rate of metal adsorption was determined to find out the shortest period of time for which equilibrium could be carried out while operating as close to equilibrium conditions as possible. Fig. 6 shows the dependence of the rate of metal ion uptake on the nature of the metal. The rate refers to the change in the concentration of the metal ions in the aqueous solution which is in contact with the given polymer. The result show that the time taken for the uptake of the different metal ions at a given stage depends on the nature of the metal ion under given conditions. It is found that $\mathrm{As}^{3+}$ ions require about $3 \mathrm{~h}$ for the establishment of the equilibrium.

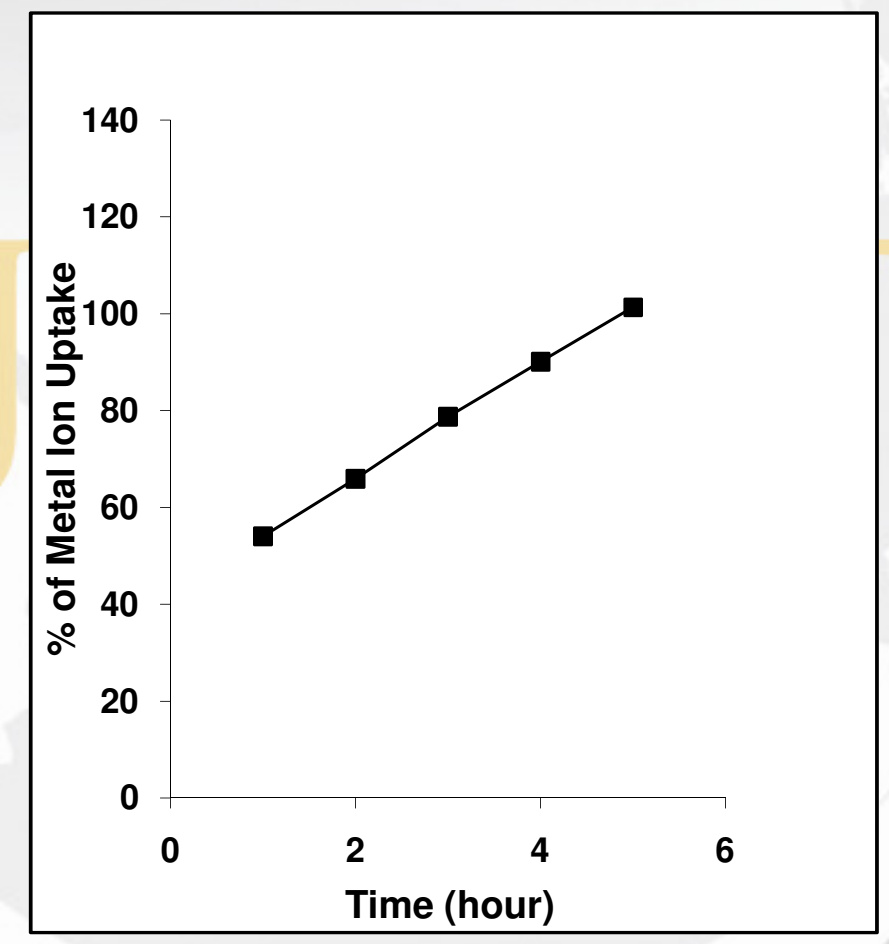

\section{Fig. 6: Comparison of the metal ion (M) uptake by $\mathrm{p}$-ABMF -I copolymer resin}

\section{Distribution Ratios of Metal Ion at Different pH}

The effect of $\mathrm{pH}$ on the amount of metal ions distributed between two phases can be explained by the result given in Fig. 7 . The data on the distribution ratio as a function of $\mathrm{pH}$ indicate that the relative amount of metal 
ions taken up by the $\mathrm{p}-\mathrm{ABMF}$ copolymer increases with increasing $\mathrm{pH}$ of the medium $^{4,5}$. The magnitude of increase, however, is different for different metal cations.

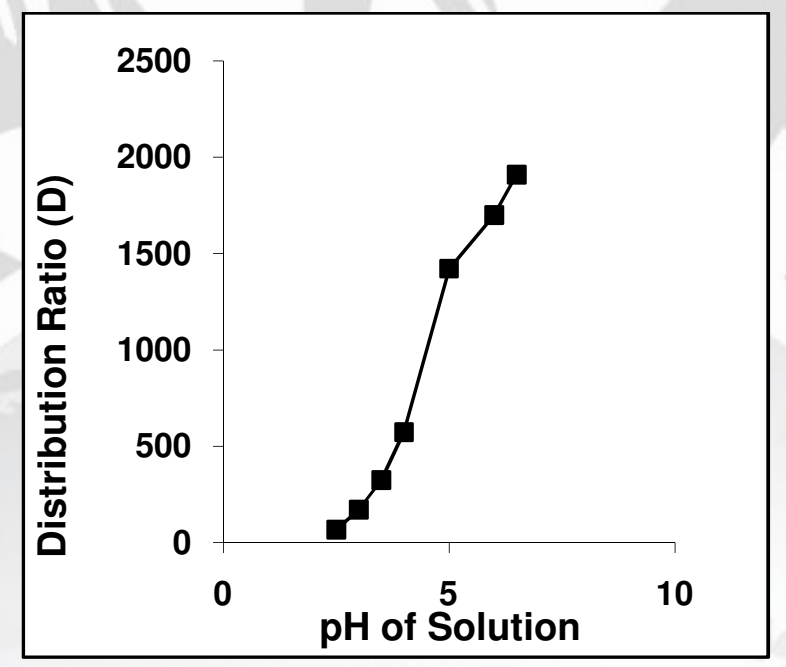

Fig. 7: Distribution ratio $D$ of various metal ions as function of the $\mathrm{pH}$ by $\mathrm{p}-\mathrm{ABMF}$-I copolymer resin

Some commercially available ion-exchange resins are given below

\begin{tabular}{|c|c|c|c|}
\hline Trade Name & $\begin{array}{c}\text { Functional } \\
\text { Group }\end{array}$ & $\begin{array}{c}\text { Polymer } \\
\text { Matrix }\end{array}$ & $\begin{array}{c}\text { Ion-exchange } \\
\text { Capacity } \\
\left(\mathrm{mmol}^{-1}\right)\end{array}$ \\
\hline $\begin{array}{c}\text { Amberlite IR- } \\
120\end{array}$ & $-\mathrm{C}_{6} \mathrm{H}_{4} \mathrm{SO}_{3} \mathrm{H}$ & Polystyrene & $5.0-5.2$ \\
\hline Duolite C-3 & $-\mathrm{CH}_{2} \mathrm{SO}_{3} \mathrm{H}$ & Phenolic & $2.8-3.0$ \\
\hline $\begin{array}{c}\text { Amberlite IRC- } \\
50\end{array}$ & $-\mathrm{COOH}$ & Methacrylic & 9.5 \\
\hline Duolite ES-63 & $-\mathrm{OP}(\mathrm{O})(\mathrm{OH})_{2}$ & Polystyrene & 6.6 \\
\hline Zeocarb-226 & $-\mathrm{COOH}$ & Acrylic & 10.00 \\
\hline Dowex-1 & $-\mathrm{N}\left(\mathrm{CH}_{3}\right)_{3} \mathrm{Cl}$ & Polystyrene & 3.5 \\
\hline $\begin{array}{l}\text { Amberlite IRA- } \\
45\end{array}$ & $\begin{array}{c}-\mathrm{NR}_{2},-\mathrm{NHR},- \\
\mathrm{NH}_{2}\end{array}$ & Polystyrene & 5.6 \\
\hline Dowex-3 & $\begin{array}{c}-\mathrm{NR}_{3},-\mathrm{NHR},- \\
\mathrm{NH}_{2}\end{array}$ & Polystyrene & 5.8 \\
\hline $\begin{array}{c}\text { Allassion A WB- } \\
3\end{array}$ & $-\mathrm{NR}_{2},-\mathrm{N}^{+} \mathrm{R}_{3}$ & Epoxy-Amine & 8.2 \\
\hline
\end{tabular}




\section{CONCLUSION:}

A copolymer $\mathrm{p}-\mathrm{ABMF}-1$ based on the condensation reaction of $\mathrm{p}$-amino benzoic acid and melamine with formaldehyde in the presence of acid catalyst was prepared. $\mathrm{p}-\mathrm{ABMF}$ is a selective chelating ion-exchange copolymer resin for certain metals. The copolymer resin showed a higher selectivity for $\mathrm{As}^{3+}$ ions. The uptake of some metal ions by the resin was carried out by the batch equilibrium technique. The uptake capacities of metal ions by the copolymer resin were $\mathrm{pH}$ dependent. From the results of distribution coefficients, it can be observed that $\mathrm{As}^{3+}$ has higher value of distribution ratio. Due to considerable difference in the uptake capacities at different $\mathrm{pH}$ and media of electrolyte, the rate of metal ion uptake and distribution ratios at equilibrium, it is possible to separate particular metal ions from their admixture by this technique.

\section{ACKNOLEDGEMENT}

The author is pleased to express his gratitude to the Director, Laxminarayan Institute of Technology, Rashtrasant Tukdoji Maharaj Nagpur University, Nagpur, VNIT Nagpur for providing the necessary laboratory facilities, and UGC for financial support.

\section{REFERENCES}

Atia A. A., Donia A. M. and Elwakeel K. Z. (2005) Selective separation of mercury (II) using synthetic resin containing amine and mercaptan as chelating groups. React Funct Polym. 65: 267.

Azarudeen R. S., Riswan M. A., Jeyakumar D and Burkanudeen AR (2009), An eco-friendly synthesis of a terpolymer resin: characterization and chelation ion-exchange property. Iran. Polym. J., 18: 821-832.

Bekir S., (2002) Synthesis of 1,4,8,11-tetraazacyclotetradecane monomer by addition of acryloyl chloride and its polymer for specific transition metal binding. J. Appl. Polym. Sci., 83 : 1406; Chem. Abstr., 136, 217085 t.

Burkanudeen R., Azarudeen M., Riswan Ahamed, P Ramesh, N Vijayan (2010), Synthesis and analytical application of a chelating resin. Int. J. Chem.

Env. Engg., 1(1) : 29-34. 
Cotton F. A., (1972), Wilkinson G. Advanced Inorganic Chemistry, 3rd ed., Wiley, New York, pp. 52.

Dutt S, Das A. K., (2007). Synthesis and characterization and application of a new chelating resin functionalized with dithiooxamide, J. Appl. Polym. Sci., 103: 2281-2285.

Gurnule W. B., Dhote S. S., (2012). Preparation, characterization and chelation ion-exchange properties of copolymer resin derived from 2,4-dihydroxy benzoic acid, ethylene diamine and formaldehyde, Der Pharma Chemica,, 4(2) : 791-799.

Gurnule W. B., Patle D. B., (2011). Metal ion binding of a copolymer resin: synthesis, characterization, and its applications. Polym. Bull., 66: 803820.

Gurnule W. B., Patle D. B., (2012), Preparation, characterization and chelating ion-exchange properties of terpolymer resins derived from oaminophenol, urea and formaldehyde. Elixir Appl. Chem.50: 1033810345.

Liu X, Zhu D and Chang D. Interaction of heavy metal ion and chelating ion exchange resin containing 8-hydroxyquinoline. Huazhong Nongye Daxue Xuebao, 19; 2000: 15; Chem. Abstr., 133, 34740w.

Lingala P. S., Paliwal L. J., Juneja H. D., (2001). Synthesis and characterization of 8-hudroxyquinoline-oxamide-formaldehyde terpolymer. Proc Nat Acad Sci Ind, 71: 205- 212.

Mane V. D., Wahane N. J., Gurnule W. B., (2009). Copolymer resin VII: 8hydroxyquinoline 5- sulphonic acid-thiourea-formaldehyde copolymer resin and their ion-exchange properties. J. Appl. Polym. Sci., 111: 3039.

Nabi S., Alim A., Islam A. and Amjad M., (2005), Column chromatographic of metal ions on 1-(2-pyridylazo) -2-naphthol modified amberlite IR 20 resin. J. Appl. Polym. Sci., 18; 2463. 
Patel S. A., Shah B. S., Patel R. M. and Patel P. M., (2004), Synthesis, characterization and ion exchange properties of acrylic copolymers derived from 8-quinolinyl methacrylate. Iran. Polym. J., 13; 445.

Rahangdale S. S., Gurnule W. B., (2012), Arsenic Removal from Potable Water Using Copolymer Resin-III Derived from p-Cresol, The IUP J. Chem.,5 (1); 7-17.

Rahangdale S. S., (2012), Synthesis and Chelation Ion-exchange Properties of 2, 4-HABF-IV Terpolymer Resin, J. Chem. Pharma. Res., 4(11); 48304835.

Shah B. A., Shah A. A. and Patel N. B.(2008), A benign approach of microwave assisted synthesis of copolymeric resin improved thermal, spectral and ion-exchange properties. Iran. Polym. J., 17(1): 3.

Singru R. N., Gurnule W. B., Khati V. A., Zade A. B., Dontulwar R. A.,(2010), Eco-friendly application of $\mathrm{p}$-cresol-melamine-formaldehyde polymer resin as ion-exchanger and its electrical and thermal study. Desalination. 263; 200-210.

Singru, R. N., Gurnule, W. B., (2010), Chelating ion-exchange properties of copolymer resins derived from p-cresol, oxamide and formaldehyde, Iran. Polym. J., 19(3): 1.

Tarase M. V., Zade A. B., Gurnule W. B., (2008), Resin I: Synthesis characterization and ion exchange properties of terpolymer resins derived from 2,4-dihydroxypropiophenone- biuret and formaldehyde. J. Appl. Polym. Sci., 108; 738-746.

Zalloum R. M. and Mubarak S. M., (2008), Chelation properties of poly (2hydroxy-4-acryloylox-ybenzophenone) resins towards some divalent metal ions. J. Appl. Polym. Sci., 109; 3180. 